\title{
Model of Ecotourism Management in Small Islands of Bunaken National Park, North Sulawesi
}

\author{
Diane Tangian ${ }^{1^{*}}$, Daniel Djokosetiyanto ${ }^{2}$, Kholil $^{3}$, Aris Munandar $^{2}$ \\ ${ }^{1}$ State Polytechnic of Manado, Manado, Indonesia \\ ${ }^{2}$ Bogor Agricultural University, Bogor, Indonesia \\ ${ }^{3}$ Sahid Jakarta University, Jakarta, Indonesia
}

\begin{abstract}
The Bunaken National Park is one of the famous national park for tourism in North Sulawesi, Indonesia. The abundance natural resources is one of the crucial natural attraction for tourism in Bunaken. Tourism in Bunaken contributes significantly in local economic development. In the same situation, however, tourism contributes negatively to environment. Tourist activities contributes significantly in coral reef covers. Utilization of natural resources as an object and attraction needs to be done carefully, taking into account the balance of ecological, socio-economic and sociocultural. The concept of ecotourism with three aspects of development were important in aspect in Bunaken National Park tourism development. The management of the park tour needs to be done based on the concept and principles of ecotourism. The Bunaken National Park tourist management model simulated by the dynamic system with the Powersim Constructor software show the number of tourist 2035 reached 27,152.98, extensive coral cover 447.87ha, the local community incomes $\mathrm{Rp} 15,834,861,419.63$ and government revenues $\mathrm{Rp} 1,751,770,691.04$.
\end{abstract}

Keywords: conservation area, ecotourism, powersim model, sustainable management.

\section{INTRODUCTION}

Bunaken National Park (BNP) is a conservation area with beauty and attractiveness of the underwater resources. The total area of $\pm 89,065$ ha area in accordance with the Decree of the Minister of Forestry No. 730 / Kpts-II / 1991 with slightly wavy morphological conditions, and is one of the most beautiful marine parks in the world. Most areas of coastline consist of mangrove forests and white sand. Prior to 1986, the area has been designated by the Government of Bunaken in North Sulawesi as a regional tourist attraction. This area is surrounded by 22 villages with a total population of around 30,000 inhabitants. Its existence is to support the tourism industry and is a source of income large enough area in North Sulawesi [1].

Bunaken National Park has 28 dive sites rich in tropical fish and coral reefs. More than 3,000 species of fish found in the area "Golden Triangle" of Papua New Guinea, the Philippines, and Indonesia. Bunaken is biologically and strategically located in the "triangle" which there are sharks, turtles, Mandarin Fish, sea horses, stingrays, and the famous Sea Kings ancient fish (the Coelacanth). There are also coral reefs both

\footnotetext{
${ }^{*}$ Correspondence address:

Diane Tangian

Email : dianetangian@yahoo.co.id

Address : State Polytechnic of Manado, Mapanget District, Manado, North Sulawesi 95252
}

soft and hard by forming a steep wall, with various kinds and colors of coral [1].

Problems that occur when this is happening in the park are environmental degradation. It is identified from less land coral cover. Currently tourism activities are generally only focused on Bunaken Island alone, so that the pressure exerted on the environment to be increasing. According DeVantier and Turak [2] visitor in Bunaken National Park more and more are turning to recreational diving activities, and this led to the degradation of coral cover more apparent.

A decrease in the percentage of live coral cover drastically occurred at a depth of $3 \mathrm{~m}$. When compared to coral cover in the survey by the BNP and Natural Resort Management (NRM) in 1998 with the results of the monitoring activities BNP in 2010, the coral covered area in 1998 changed from $72.1 \%$ to $33.24 \%$ in 2010 . Dutton et al. in Supit [3] states that the increase in human activity in the utilization of coral reef ecosystems can cause damage to the coral reef ecosystem itself. For that in efforts to use natural resources as objects and tourist attraction, need a management plan carefully because it may have an impact on the environment. Tourism as an industry must really have good planning, implementation and evaluation, so that the negative impacts of tourism can be tolerated [4].

Based on the above mentioned problems, the management of Bunaken National Parks should 
be done with reference to the concept of ecotourism, so that tourism can be realized in a sustainable manner. Development of sustainable tourism policies can be a useful way to encourage new forms of business, increase employment and promote conservation [5]. Sustainable tourism development should be based on actual analysis of the potential environmental, social, cultural and economic soaial utilized to improve the welfare of local communities $[1,6]$.

Ecotourism is a concept that has to accommodate tourism demand and tourism supply, where it is seen in the six elements that follow the concept of ecotourism: conservation, education, ethics, sustainable development, local impact and benefits [7]. The concept of ecotourism is a concept that is capable of bridging the interests of environmentalists with the tourism industry. Based on these problems, the goal of this research is to create a model of sustainable tourism management BNP. BNP travel management model simulated in dynamic systems, with the help of software Powersim Constructor to provide an overview of system behavior both present and future.

\section{MATERIALS AND METHODS}

The research was conducted in Bunaken National Park in North Sulawesi province, which began in August of 2011 (Figure 1). Data used in the form of primary data, ie expert opinions, interviews with residents, employers and workers in tourism. Secondary data include extensive coral cover, the number of tourists, admission to Bunaken National Park, literature and previous studies associated with this research.
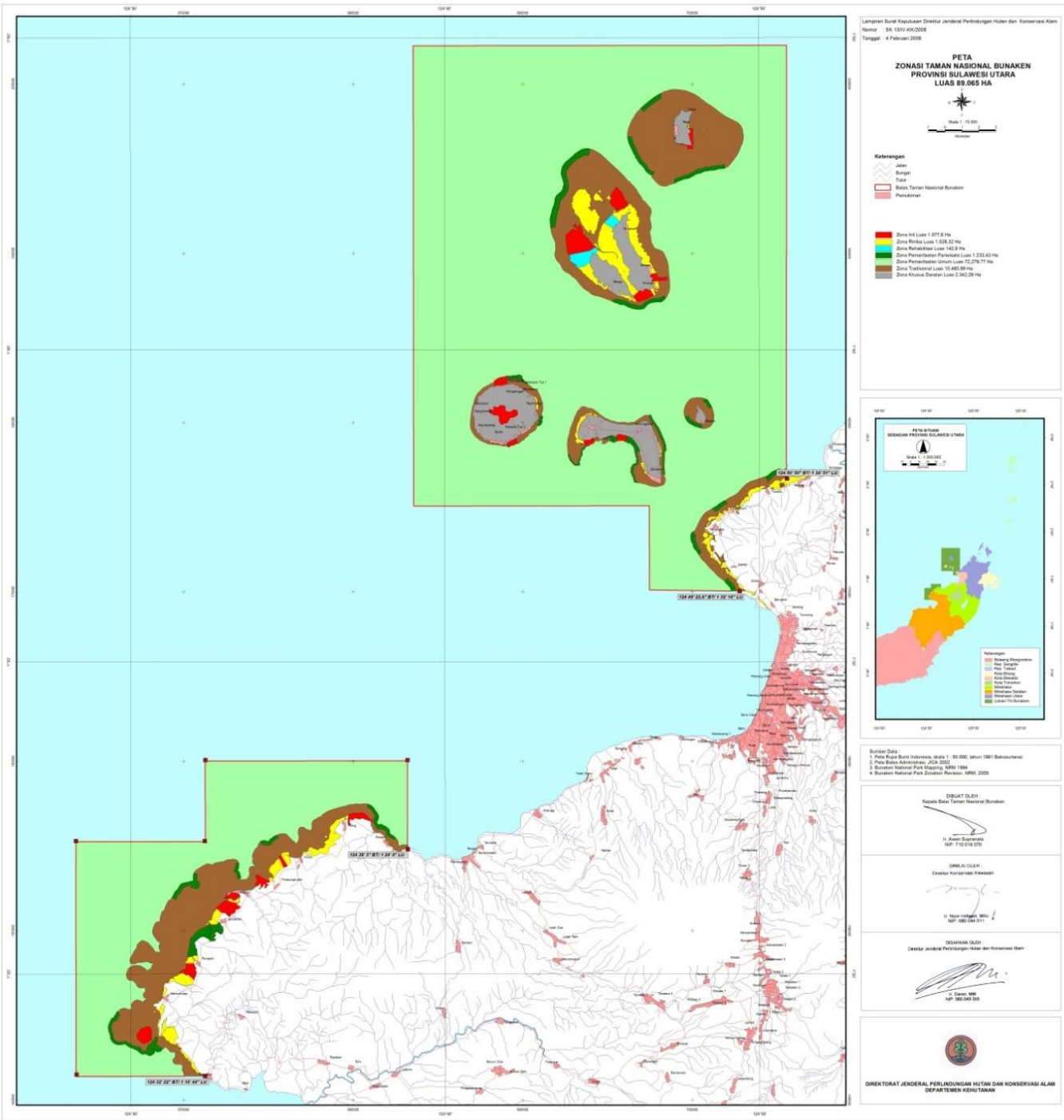

Figure 1. Map of Research Location [8] 


\section{Data Collection}

At this stage of the assessment sub-model of ecotourism data is required in the form of extensive coral coverage, quality of service and promotion, while public revenue is income from the rental of the boat. Diving equipment rental, restaurants, lodging, guides, and selling souvenirs. Further for the government revenues, the data needed were derived from the sale of admission tickets tourists, and levy of ship. These data were obtained through questionnaires and interviews with local people.

\section{Data Analysis}

Furthermore, the data were processed using Microsoft Excel, and the built model was simulated in dynamic systems with the help of software Powersim Constructor, to provide an overview of system behavior both present and future. The next stage is to test the model validation is the validation test structure and performance validation test. AME (means absolute error) is the deviation between the average value of the actual simulation. AVE (absolute error variation) is the deviation of the actual value of the variation simulation. Limit of acceptable deviation is $5-10 \%$ [9]. The formula for calculating the AME and AVE are:
AME (absolute means error) $=(\mathrm{Si}-\mathrm{Ai}) / \mathrm{N}$

$\mathrm{Si}=\mathrm{Si} / \mathrm{N}$ and $\mathrm{Ai}=\mathrm{Ai} / \mathrm{N}$

Description: $\quad \mathrm{S}=$ Value simulation

$A=$ Actual value

$\mathrm{N}=$ Interval time of observation

AVE (absolute variation error) $=(\mathrm{Ss}-\mathrm{Sa}) / \mathrm{Ai}$

Description: $\quad \mathrm{Ss}=((\mathrm{Si}-\mathrm{Si}) 2 / \mathrm{N})$

$\mathrm{Sa}=((\mathrm{Ai}-\mathrm{Ai}) 2 / \mathrm{N})$

$\mathrm{N}=$ Interval time of observation

\section{RESULTS AND DISCUSSION}

Ecotourism management model in BNP is built on a set of relationships between the statement of needs and the statement of the problem to be solved in order to meet those needs. The concept modeling is based on the situation and the problems that occur today in BNP. The identification of models that are built can be seen in Fig. 2, where the number of tourist arrivals will affect the vast coral cover, and vice versa extensive coral cover will affect the number of tourists. Furthermore, the number of tourist visits and extensive coral cover will also affect people's incomes and government revenues, and household incomes and government revenues will affect the promotion and quality of service. It is apparent that each element in the model built will have interrelated relationships and mutually influence each other.

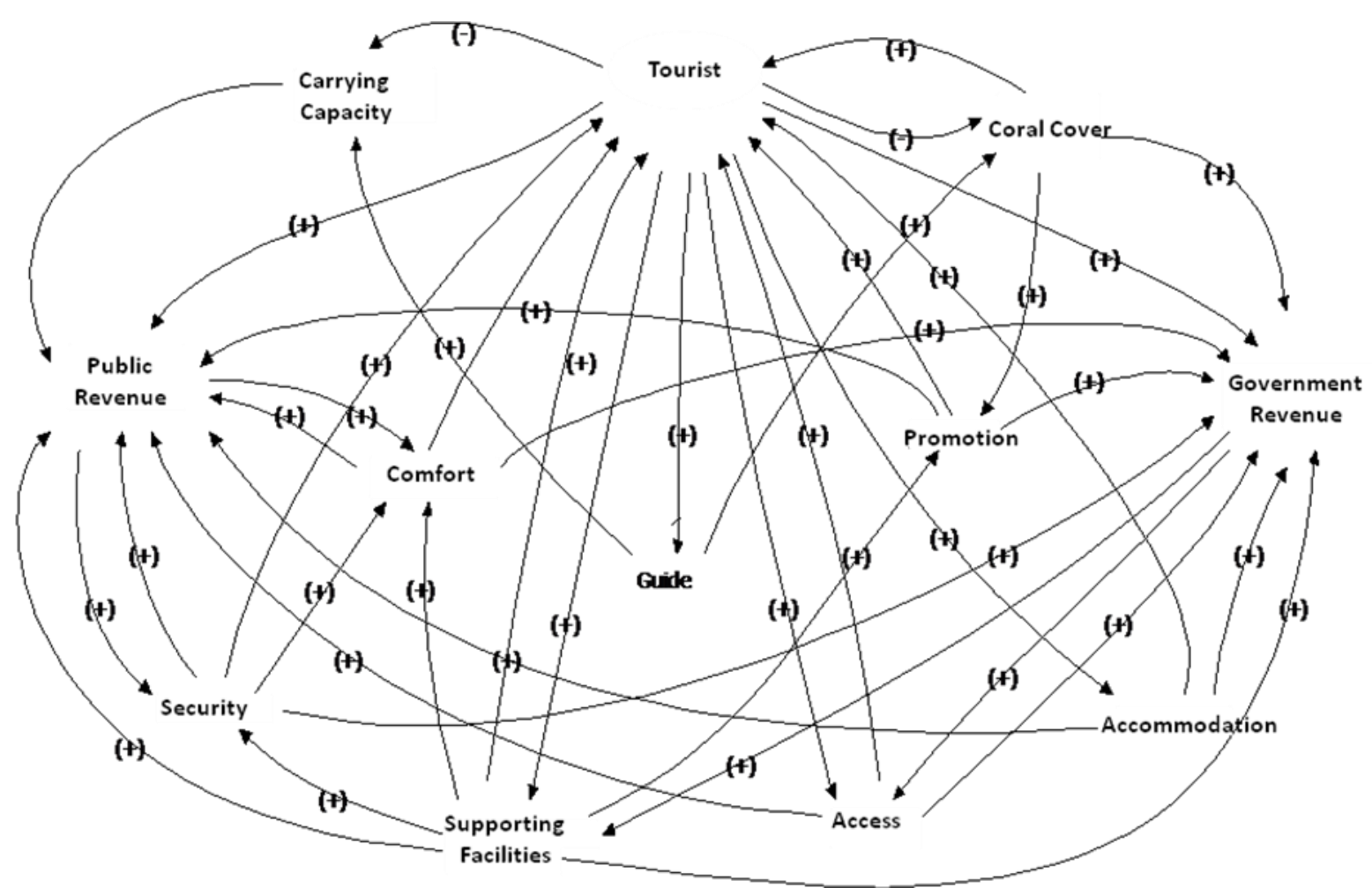

Figure 2. Diagram of circumference causal (causal loop) management of Bunaken National Park 


\section{Simulation of Model Management of Bunaken} National Park Ecotourism

Making the management model of Bunaken National Park aims to determine the concept of ecotourism management of BNP in order to run a sustainability, both from the ecological and socioeconomic aspects. The concept of model built (Fig. 3) is the application on the influence of tourism visits to the existence of coral reefs, public revenue and government income.

Some of the key variables in the sub ecotourism models are: 1) rating, 2) promotion, $3)$ the print media, 4) electronic media, 5) exhibit, 6) quality of service, 7) access, 8) accommodation, 9) guide, 10) security, 11) comfort, 12) supporting facilities, 13) coral cover, and 14) carrying capacity. The key variables of sub public revenue models are: 1) guide, 2) resort and diving center, 3) speed boat, 4) souvenirs, 5) snorkeling equipment rental, 6) restaurant, 7) long boat, 8) sub-sea vessels, 9 ) catamaran, 10) boats, and 11) cottages. Further sub key variables government revenue model consists of: 1) admission of domestic, 2) admission of foreign tourists, 3) levie of $40 \mathrm{hp}$ motor boats, 4) levy of $80 \mathrm{hp}$ motor boats, and 5) levy of motor boats above $80 \mathrm{hp}$.

\section{Scenario Simulation Model Management of Ecotourism Bunaken National Park.}

Simulation models are built based on current conditions (existing condition) of each of the key variables, and as time goes by key variables can be changed. Based on this further prepared various scenarios strategies that can be carried out for management of BNP in order to run in a sustainable manner.

The model scenario in the sub model of ecotourism made of the number of visitors, extensive coral cover, people's income, and government revenues. Based on the model that was built where the promotion and quality of service will affect the increase in the number of tourist arrivals and the number of tourists will also affect people's incomes, government revenues, and extensive coral cover. Vice versa extensive coral cover will affect the number of tourists, people's income, and government revenues. The people's incomes and government revenues will affect the promotion and quality of service. The equations used in tourist number are as follows:

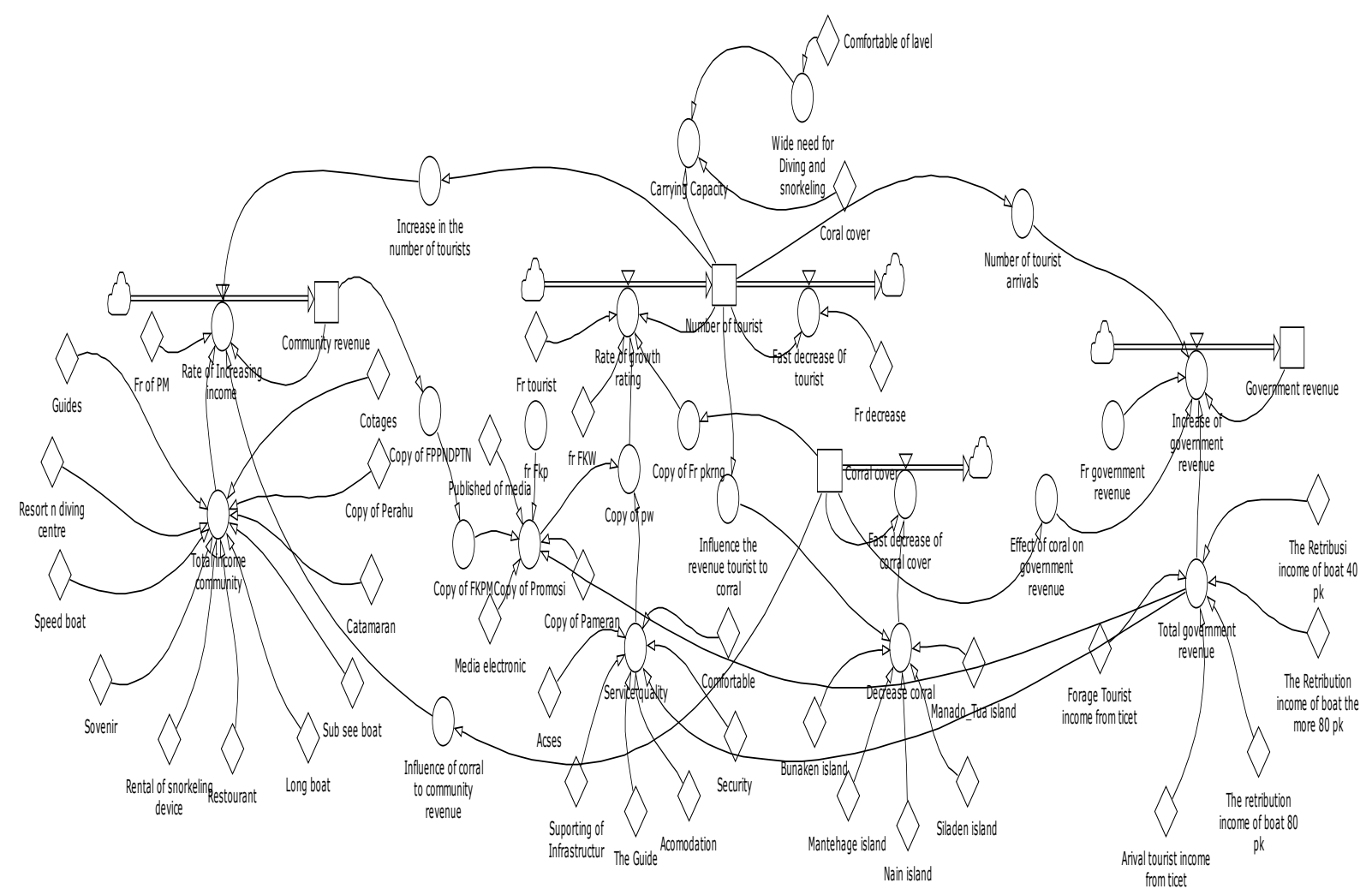

Figure 3. Structure of the dynamic model of ecotourism management in Bunaken National Park 


\section{JKW = LPW - LTW}

Description: $\quad J K W=$ number of tourist arrivals $\mathrm{LPW}=$ rate of growth rating PTW $=$ The rate of decline in tourists

While

LPW $=\mathrm{JW} \times$ FK $\times$ PW $\times$ FKW $\times$ FW LTW $=$ JW $x$ FPW

Further

$$
P W=(P+K) / 2
$$

Description: $J W=$ Number of tourists

$\mathrm{FK}=$ Fraction of coral

$\mathrm{PW}=$ Effect of promotion and service quality of the number of tourists FKW = correction factor rating

$\mathrm{FW}=$ Fraction of travelers

$\mathrm{P}=$ Promotion

$\mathrm{K}=$ Quality of service

While the equations used for coral cover are:

\section{TK = PK $x$ LK}

Description: $\quad$ TK $=$ Coral cover

LK = Area of coral cover

PK =The decline of coral

While

PK = TKP / $5 \times$ PWK

Description: TKP $=$ Decrease in five coral islands $P W K=$ Effect of the number of tourists on the reef

The equation used for public revenue is:

JPM = PM $\times$ FPM $\times$ PKM $\times$ TPM $\times$ PWM

Description: $J P M=$ Total public revenue

$\mathrm{PM}=$ Community revenue

$F P M=$ fraction public revenue

TPM = Total income communities

PKM = Effect of coral on public Revenue

PWM = Effect of the number of tourists to the income of the people

The equation for government revenue is:

$$
\begin{aligned}
\text { JPP }=\text { PP } \times \text { TPP } \times \text { FPP } \times \text { PKP } \times \text { PWP } \\
\text { Description: } \quad \text { JPP }=\text { Total government revenue } \\
\mathrm{PP}=\text { Government revenue } \\
\mathrm{FPP}=\text { Fraction of government revenue } \\
\mathrm{TPP}=\text { Total government revenue } \\
\mathrm{PKP}=\text { Effect of coral on government } \\
\\
\quad \text { Revenue } \\
\mathrm{PWP}=\text { Traveler Effect on government } \\
\text { revenue }
\end{aligned}
$$

Furthermore ecotourism scenario of Bunaken National Park can be seen in Fig. 4 which clearly visible causal relationship between the number of tourist visits, extensive coral cover, people's income, and government revenues. The increasing number of tourists visiting the extensive coral cover has declined, but unlike the case with household incomes and government revenues that will increase if the number of tourists increased. This is consistent with previous studies conducted by Supit [3] which states that tourist arrivals has significant effect on coral cover percentage.
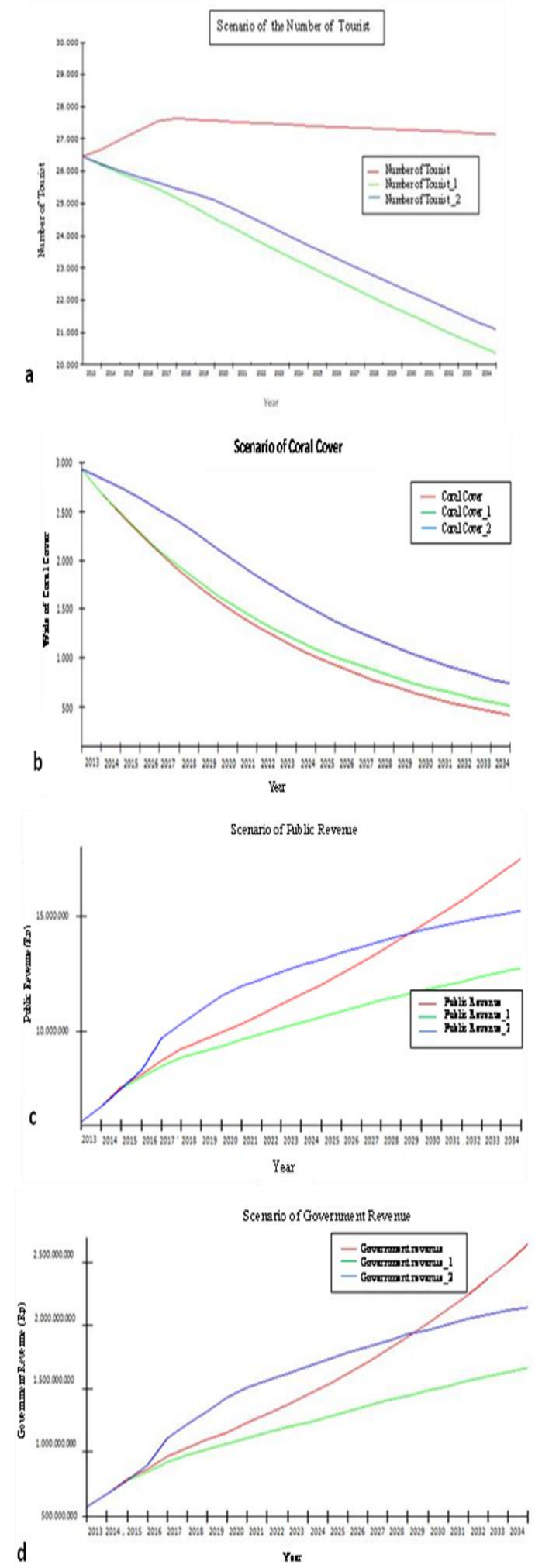

Figure 4. Simulation Scenario in BNP; a) tourism number, b) coral cover, c) public revenue, d) Government Revenue 


\section{Number of Tourist}

Based on the scenario of simulations conducted where the number of tourist arrivals increased until 2019, while the year after decreased. In 2013 the number of tourists is 26,454 , and in 2019 the number of tourists reaches 27,600, while years later it appears that every year there is an average decline of nearly $10 \%$ up on 2035 (Table 1). This occurs along with the reduced extensive coral cover, then the number of tourist arrivals will also decrease if the object and appeal offered beauty of BNP decreased.

Based on the number of tourist arrivals the number of tourists visiting BNP has exceeded the carrying capacity, which limits the carrying capacity of 4000-6000 dives/site/year [2]. Meanwhile, according to Hawkin and Roberts in Supit [3] recommends 5000-6000/dives/site/year can be used to estimate an overall capacity of protected areas to support recreational diving, depending on the number of dive sites available. This is an issue for national parks, where the national park is a conservation area which is used as an object and tourist attraction which should prioritize conservation than utilization.

In terms of tourism, the more tourists are visiting, the more successful tourism is considered because it can attract tourists to visit the area. Economically, tourism also considered successful, because it can boost the economy and welfare of the community, which ranks tourism foreign exchange against 10 largest goods export which was ranked fifth with a contribution amounting to 8,554.40 million USD [10]. However, if viewed in terms of environmental sustainability, tourism is considered as one causes of environmental damage.

Based on these problems, the management should pay attention to the balance between ecological, socio-economic and socio-cultural [1]. According to Dutton et al. in Supit [3], increase of human activities in the utilization of coral reef ecosystems can cause damage to the coral reef ecosystem itself. Management should consider the balance between the environmental, socioeconomic and socio-cultural, but in fact the environment has always been far behind the economy [11]. Stakeholders should pay attention to the sustainability of the important dimensions of governance of protected areas [1,12].

Furthermore, Table 1 showed differences in the number of tourist arrivals figures in column 1 , 2 and 3, where the number of tourists_ 1 (column 2 ) and the number of tourists_2 (column 3), has received the intervention while the number of tourists in column 1 without intervention. The interventions were carried out on tourist numbers_1, which only restrict the number of visits, while the number of tourists_ 2 in addition for limiting the number of visits made also revamping the entrance, as well as optimal utilization of the overall tourist objects that exist. As for the attractions in the form of natural attractions, tourist artificial, culinary tourism, as well as arts and culture both within and around the area of Bunaken National Park. The national park is a repository of unique natural scenery, cultural assets and historic resources are good as a tourist site $[13,14]$. The aim is for tourist activities not only to be focused on Bunaken National Park alone, so that the environment can be maintained.

Table 1. Results of the simulation the number of tourists.

\begin{tabular}{cccc}
\hline Year & $\begin{array}{c}\text { Number of } \\
\text { tourist }\end{array}$ & $\begin{array}{c}\text { Number of } \\
\text { tourist_1 }\end{array}$ & $\begin{array}{c}\text { Number of } \\
\text { tourist_2 }\end{array}$ \\
\hline 2013 & 26,454 & 26,454 & 26,454 \\
2014 & 26,678 & 26,188 & 26,220 \\
2015 & 26,973 & 25,942 & 26,010 \\
2016 & 27,251 & 25,684 & 25,824 \\
2017 & 27,554 & 25,454 & 25,650 \\
2018 & 27,641 & 25,172 & 25,417 \\
2019 & 27,600 & 24,857 & 25,283 \\
2020 & 27,563 & 24,547 & 25,095 \\
2021 & 27,530 & 24,241 & 24,854 \\
2022 & 27,498 & 23,940 & 24,863 \\
2023 & 27,468 & 23,642 & 24,277 \\
2024 & 27,440 & 23,349 & 23,994 \\
2025 & 27,412 & 23,060 & 23,714 \\
2026 & 27.386 & 22,774 & 23,439 \\
2027 & 27,360 & 22,492 & 23,166 \\
2028 & 27,334 & 22,213 & 22,897 \\
2029 & 27,308 & 21,938 & 22.631 \\
2030 & 27,282 & 21,666 & 22,368 \\
2031 & 27,256 & 21,398 & 22,108 \\
2032 & 27,230 & 21,133 & 21,851 \\
2033 & 27,204 & 20,871 & 21,597 \\
2034 & 27,178 & 20,612 & 21,345 \\
2035 & 27,152 & 20,357 & 21,097 \\
\hline
\end{tabular}

\section{Coral Cover}

Coral cover shows the extensive decreases each year (Table 2). In 2013, extensive coral cover in the five islands of Bunaken National Park is 2,935.32 ha, whereas in 2035 decreases to 447.87 ha. This certainly must get the government's attention to maintain the sustainability of coral ecosystems that exist in Bunaken National Park, because the travel management must pay attention to the carrying capacity of the environment especially marine tourism offered is a fragile ecosystems [15]. Coral reef ecosystems than can be used as an object 
and attraction also serves as a source of food supply for human needs, protection to tropical islands, and as a source of foreign exchange $[16,17]$.

Travel management requires government support through policies related to the use of nature as an object and tourist attraction, regard to the carrying capacity of the environment so that sustainable tourism can be achieved [1]. Management by promoting economic terms alone, in the end will not commensurate with the expenditure to overcome the effects of environmental damage caused. Appropriate policy interventions have the power and positive influence on sustainable tourism $[18,19]$.

Table 2 also shows the vast differences in coral cover in which to extensive coral cover 1 and vast coral cover 2 got such interventions carried out on the number of tourist arrivals, while extensive coral cover in the first column is without any intervention. The rate of decline in coral cover 2 with interventions optimize the full potential of existing attractions, both in BNP and surrounding area. Subsequent interventions such as the promotion of negative impacts on the environment due to exceeded number of visitors over the carrying capacity, to raise awareness and affection of the people and tourists to the environment [20].

Table 2. Results of extensive simulation on coral cover

\begin{tabular}{rrrr}
\hline Year & $\begin{array}{c}\text { Corral Cover } \\
\text { (Ha) }\end{array}$ & $\begin{array}{c}\text { Corral } \\
\text { Cover_1 (Ha) }\end{array}$ & $\begin{array}{c}\text { Corral } \\
\text { Cover_2 (Ha) }\end{array}$ \\
\hline 2013 & $2,925.32$ & $2,295.32$ & $2,925.32$ \\
2014 & $2,693.55$ & $2,693.55$ & $2,841.88$ \\
2015 & $2,478.35$ & $2,482.28$ & $2,745.92$ \\
2016 & $2,278.14$ & $2,289.41$ & $2,638.96$ \\
2017 & $2,092.20$ & $2,113.23$ & $2,520.58$ \\
2018 & $1,919.54$ & $1,952.13$ & $2,392.77$ \\
2019 & $1,760.63$ & $1,804.95$ & $2,260.43$ \\
2020 & $1,615.09$ & $1,670.57$ & $2,125.21$ \\
2021 & $1,481.76$ & 1.547 .75 & $1,991.83$ \\
2022 & $1.259,58$ & $1,435.38$ & $1,861.36$ \\
2023 & $1,257.61$ & $1,332.46$ & $1,738.12$ \\
2024 & $1,144.97$ & $1,238.11$ & $1,621.85$ \\
2025 & $1,050.87$ & $1,151.53$ & $1,513.46$ \\
2026 & 964.59 & $1,072.00$ & $1,412.41$ \\
2027 & 885.57 & 998.88 & $1,318.22$ \\
2028 & 812.91 & 931.59 & $1,230.41$ \\
2029 & 746.36 & 869.61 & $1,148.98$ \\
2030 & 685.32 & 812.47 & $1,073.44$ \\
2031 & 629.32 & 759.75 & $1,003.33$ \\
2032 & 577.95 & 711.06 & 938.22 \\
2033 & 530.81 & 666.05 & 878.05 \\
2034 & 487.56 & 624.42 & 822.39 \\
2035 & 477.87 & 585.87 & 770.87 \\
\hline Based & on the & differences intervention in \\
extensive & coral cover 1 and vast coral & cover 2, it
\end{tabular}

is clear that there are vast differences in coral cover. Extensive coral cover 2 is larger than the vast coral cover 1 which just received the intervention in the form of restrictions on the number of tourist visits. Tourist behavior has now changed where the majority of today's travelers desire recreational tourism, plus which in addition to enjoying the uniqueness of the local environment, they also makr an active interaction with the local community to know more about the culture, customs, traditions and social values of society [21].

\section{Community Revenue}

Public or community revenue (income) increased to Rp. 15,834,861,420 in 2035 (Table 3). Total revenue were obtained from the amount of revenue that has not been reduced by the cost/operational expenditures. Public revenue (column 1) increase each year, while the amount of public revenue_1 (column 2) decreased compared to the amount of public revenue (column 1). Public income 1 (column 2) intervented by restrictions on the number of tourist visits, thereby affecting the amount of public revenue.

Table 3. Simulation of community revenue

\begin{tabular}{rrrr}
\hline Year & $\begin{array}{c}\text { Community } \\
\text { Revenue }\end{array}$ & $\begin{array}{c}\text { Community } \\
\text { Revenue_1 }\end{array}$ & $\begin{array}{c}\text { Community } \\
\text { Revenue_2 }\end{array}$ \\
\hline 2013 & $6,064,277,578$ & $6,064,277,578$ & $6,064,277,578$ \\
2014 & $6,759,812,080$ & $6,759,812,080$ & $6,759,812,080$ \\
2015 & $7,558,717,848$ & $7,500,354,706$ & $7,507,072,217$ \\
2016 & $8,403,591,630$ & $7,910,390,237$ & $8,301.273,149$ \\
2017 & $8,571,393,694$ & $8,319,067,415$ & $9,594,411,879$ \\
2018 & $8,968,037,833$ & $8,614,959,109$ & $10,121,146,798$ \\
2019 & $9,283,234,448$ & $8,819,937,743$ & $10,630,565,869$ \\
2020 & $9,607,744,721$ & $9,017,004,142$ & $11,136,732,130$ \\
2021 & $9,941,996,033$ & $9,205,608,915$ & $11,519,548,412$ \\
2022 & $10,286,333,578$ & $9,385,212,223$ & $11,776,735,697$ \\
2023 & $10,641,121,196$ & $9,555,308,685$ & $12,023,940,505$ \\
2024 & $11,006,681,616$ & $9,715,417,800$ & $12,260,585,771$ \\
2025 & $11,383,350,345$ & $9,865,097,574$ & $12,485,731,276$ \\
2026 & $11,771,476,297$ & $10,003,946,449$ & $12,699,076,558$ \\
2027 & $12,171,422,444$ & $10,131,604,942$ & $12,899,963,552$ \\
2028 & $12,583,479,162$ & $10,247,744,992$ & $13,087,860,068$ \\
2029 & $13,088,015,110$ & $10,352,082,930$ & $13,262,280,309$ \\
2030 & $13,445,297,307$ & $10,444,380,384$ & $13,422,786,847$ \\
2031 & 13.895 .671 .197 & $10,524,444,884$ & $13,568,992,272$ \\
2032 & $14,359,470,722$ & $10,592,130,173$ & $13,700,560,548$ \\
2033 & $14,837,036,391$ & $10,647,336,224$ & $13,817,208,014$ \\
2034 & $15,328,751,344$ & $10,690,008,979$ & $13,918,704,099$ \\
2035 & $15,834,861,420$ & $10,720,139,811$ & $14,004,871,688$ \\
\hline & & &
\end{tabular}

Total income of community 2 increased compared to the amount of income of the people first started in 2016. This occurs due to the interventions at the community revenue 2 that optimize the full potential of objects and tourist 
attraction. In addition, Manado has interesting art and culture that can be used as objects and tourist attraction. Mapalus culture (mutual assistance), thanks giving celebration, and artistic attractions (Maengket, Cakalele, Masamper, Kabasaran dance), and historical heritage need to be packaged attractively, thus the pressure on the environment as a result of tourism activities can be minimized [20].

\section{Government Revenue}

The number of government revenue in 2013 increase in 2035. Government revenues_1 in 2035 decreases, while the number of government revenues_2 increased (Table 4).

Table 4. Simulation results of government revenue

\begin{tabular}{rrrr}
\hline Year & $\begin{array}{c}\text { Government } \\
\text { Revenue }\end{array}$ & $\begin{array}{c}\text { Government } \\
\text { Revenue_1 }\end{array}$ & $\begin{array}{c}\text { Government } \\
\text { Revenue_2 }\end{array}$ \\
\hline 2013 & $570,979,000$ & $570,979,000$ & $570,979,000$ \\
2014 & $647,825,588$ & $647,825,588$ & $647,825,558$ \\
2015 & $737,668,470$ & $731,105,139$ & $731,860,570$ \\
2016 & $793,195,823$ & $778,006,384$ & $822,716,443$ \\
2017 & $854,271,225$ & $825,172,539$ & $973,105,222$ \\
2018 & $900,659,712$ & $859,612,903$ & $1,035,795,240$ \\
2019 & $937,805,510$ & $883,613,561$ & $1,096,971,648$ \\
2020 & $976,274,143$ & $906,780,800$ & $1,158,262,735$ \\
2021 & $1,016,129,646$ & $929,037,335$ & $1,204,982,920$ \\
2022 & $1,057,427,240$ & $950,306,960$ & $1,236,551,843$ \\
2023 & $1,100,225,212$ & $970,517,594$ & $1,267,101,388$ \\
2024 & $1,144,577,723$ & $989,600,283$ & $1,296,259,485$ \\
2025 & $1,190,541,244$ & $1,007,490,940$ & $1,324,204,577$ \\
2026 & $1,138,174,675$ & $1,024,130,697$ & $1,350,756,052$ \\
2027 & $1,287,539,471$ & $1,039,466,219$ & $1,375,829,927$ \\
2028 & $1,338,691,165$ & $1,053,448,531$ & $1,399,345,731$ \\
2029 & $1,391,686,781$ & $1,066,034,658$ & $1,421,229,298$ \\
2030 & $1,446,584,854$ & $1,077,187,823$ & $1,441,413,125$ \\
2031 & $1,503,445,469$ & $1,086,877,696$ & $1,459,836,708$ \\
2032 & $1,562,330,281$ & $1,095,079,989$ & $1,476,446,826$ \\
2033 & $1,623,302,550$ & $1,101,777,510$ & $1,491,197,763$ \\
2034 & $1,686,427,168$ & $1,106,959,164$ & $1,504,051,490$ \\
2035 & $1,751,770,691$ & $1,110,620,415$ & $1,514,977,779$ \\
\hline & & &
\end{tabular}

The difference in the number of government revenue is happening because of the amount of revenue of the government first received intervention in the form of restrictions on the number of tourist arrivals, thus automatically affect the amount of government revenue_1.

Total government revenues_2 increases, because the received interventions that optimize the full potential of objects and tourist attraction there. The intervention has a positive impact where the number increased government revenue and environmental sustainability of Bunaken National Park can be maintained.

\section{Model and Performance Validation}

The next stage is to test the model validation, with structure validation test and performance validation test. AME (means absolute error) is the deviation between the average value of the actual simulations, while the AVE (absolute error variation) is the deviation of the actual value of the variation simulation, with an acceptable deviation limit which is a maximum of $10 \%$ [9]. AME validation test results (absolute means error) shows the number of tourist arrivals to $0.03,0.02$ people's income, government revenue 0.03 , and extensive coral cover was 0.04 or wholly on average below $5 \%$ so the results of this model structure can be said to be accurate and acceptable (Table 5). Furthermore, Table 6 the results of the validation test AVE (absolute variation of error) shows the number of tourist arrivals of $0.03,0.02$ people's income, government revenue 0.03 , and extensive coral cover 0.04. These results indicate that the performance validation tests of this model is acceptable because the average is under $5 \%$.

Table 5. Results of the validation test AME

\begin{tabular}{cccccc}
\hline Year & AME The Number of & AME Income & AME Government & AME Extensive Coral \\
& Tourist & Communities & Revenue & $?$ & Cover \\
2013 & $?$ & 0.00 & 0.00 & 0.00 \\
2014 & 0.00 & 0.02 & 0.03 & 0.04 \\
\hline
\end{tabular}

Table 6. Results of the validation test AVE

\begin{tabular}{|c|c|c|c|c|}
\hline Year & $\begin{array}{c}\text { AVE The Number of } \\
\text { Tourist }\end{array}$ & $\begin{array}{l}\text { AVE Income } \\
\text { Communities }\end{array}$ & $\begin{array}{c}\text { AVE Government } \\
\text { Revenue }\end{array}$ & $\begin{array}{c}\text { AVE Extensive Coral } \\
\text { Cover }\end{array}$ \\
\hline 2013 & $?$ & $?$ & $?$ & $?$ \\
\hline 2015 & 0.03 & 0.02 & 0.03 & 0.04 \\
\hline
\end{tabular}




\section{CONCLUSION}

Based on the results of analysis, the number of tourists visiting has a real connection with extensive coral cover. Increase on the number of tourist arrivals will affect the broad decline in coral cover, and vice versa. Otherwise, decline in coral cover will cause the number of tourists to decrease. Increase of the number of tourist arrivals occur until 2019, and the next year there will be a decrease in the number of tourists due to the decline of extensive coral cover. The number of tourist arrivals in 2035 became 27,152 and extensive coral cover was reduced to 447,87 ha. Furthermore, household incomes and government revenues in 2035 respectively to $\mathrm{Rp}$ $15,834,861,420$ and $R p 1,751,770,691$.

The first intervention is done on the number of tourist visits, extensive coral cover, communities incomes and government revenues in the form of restrictions on the number of tourist visits. Results indicate that on each element of a decline compared to the first results without intervention, while the second intervention has increased when compared to the intervention 1 . The number of tourists in 2035 the first intervention to decrease until it reaches 20357 tourists, and the second intervention increased compared to 1 , reaching intervention 21.097 tourists.

Extensive coral cover in 2035 on one intervention increased compared with the one without intervention, that is from 447.87 to 585.87 ha, while the second intervention increases to 770.87 ha. Income communities in the intervention 1 total revenues decreases to Rp. $10,720,139,811$, and the second intervention has increased to Rp. $14,004,871,688$. Further for government revenues in 2035 with the first intervention decreasesfrom Rp. 1,751,770,691 to Rp 1,110,620,415 and the second intervention increases to Rp. 1,514,977,779. Based on the results of the validation structure test and performance validation test (AME and AVE) showed each below $5 \%$, thus this model can be said to be accurate and acceptable.

\section{REFERENCES}

[1] Hakim, L., Soemarno, and S. K. Hong. 2012. Challenges for conserving biodiversity and developing sustainable island tourism in North Sulawesi Province, Indonesia. Journal of Ecology and Field Biology 35 (2), 61-71.

[2] DeVantier, L. and E. Turak. 2004. Managing tourism in Bunaken National Marine park and adjacent waters, North Sulawesi,
Indonesia. Technical Report by the Natural Resouces Management Program III, Indonesia.

[3] Supit, A. A. G. 2007. Impact of tourism visit toward change of coral reefs condition in Bunaken Island North Sulawesi Province. Master Thesis. Environmental Studies Program, Bogor Agricultural University. Bogor. Unpublished.

[4] Mangkudilaga, S. 2000. Role of tourism and poverty alleviation. Environmental Scientific Management 2 (7), 9-16.

[5] Castellani, V. and S. Sala. 2010. Sustainable performance index for tourism policy development. Journal of the Tourism Management 31, 871-880.

[6] Rydin, Y., N. Holman, and E. Wolff. 2003. Local sustainability indicators. Local Environment 8 (6), 581-589.

[7] McIntosh, R. W., C. R. Goeldner, and J. R. B. Ritchie. 1995. Tourism principles, practice philosophies. Willey. New York.

[8] Bunaken National Park. 2008. Zonation of Bunaken National Park, Nort Sulawesi. Office of BUnaken National Park.

[9] Muhammadi, E. Aminullah, and B. Susilo. 2001. Analysis of dynamic systems. Environmental, Social, Economic, Management. Jakarta Muhammadiyah University Press. Jakarta.

[10] BPS, 2013. Indonesian Tourism Statistics. Ministry of Tourism and Economic Creative. Jakarta.

[11] Eryadi, A., H. Erkus, and Ozturk. 2010. Environmental governance for sustainable tourism development: collaborative networks and organization building in the Antalya Tourism Region. Journal of the Tourism Management 31, 113-124.

[12] Bawole. 2012. Analysis and mapping of stakeholders in traditional use zone within the Marine Protected Area. Journal of Tropical Forest Management (2), 110-117.

[13] Hvenegaard, G. T. and P. Dearden. 1998. Ecotourism versus tourism in a Thai National Park. Annals of Tourism Research 25 (3), 700-720.

[14] Tsai, W. H., W. C. Chou, and C. W. Lai. 2010. An effective evaluation and improvement analysis model for National Park. A case study of Taiwan. Journal of the Tourism Management 31, 936-952.

[15] Soemarwoto, O. 2004. Ecology, environment and development. Djambatan. 
[16] Moberg, F. and C. Folke. 1999. Ecological goods and services of coral reef ecosystems. Ecological Economics 29 (2), 215-233.

[17] Bawole, R., V. Rumere, Mudjirayu, and T. F. Pattiasina. 2013. Performance of coral reef management within marine protected areas:integrating ecological, socioeconomic, technological, and institutional dimension. Journal of Tropical Forest Management 19 (1), 63-73.

[18] Pigram, J.J. 1990. Sustainable tourism-policy considerations. Journal of Tourism Studies 1 (2), 2-9.

[19] Munandar, A. 2006. Ecotourism policy analysis and development. Lecture materials. Bogor Agricultural University. Bogor.

[20] Fennell, D. A. 2003. Ecotourism: an introduction, Special Edition. Routledge. London and New York.

[21] Sekartjakrarini, S., and N. K. Legoh. 2004. National ecotourism strategy plan. Jakarta Center. Office of the State Minister of Culture and Tourism of Indonesia. Jakarta. 